\title{
Technologies for the Production of Fertilizable Mammalian Oocytes
}

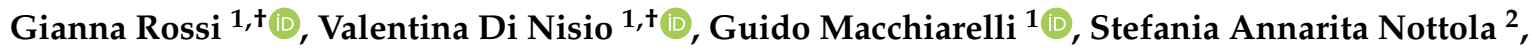 \\ Iman Halvaei ${ }^{3}{ }^{(D)}$, Lucia De Santis ${ }^{4}$ and Sandra Cecconi ${ }^{1, *}$ \\ 1 Department of Life, Health \& Environmental Sciences, University of L'Aquila, 67100 L'Aquila, Italy; \\ gianna.rossi@univaq.it (G.R.); valentina.dinisio@graduate.univaq.it (V.D.N.); gmacchiarelli@univaq.it (G.M.) \\ 2 Department of Anatomy, Histology, Forensic Medicine and Orthopaedics, Sapienza University, 00185 Rome, \\ Italy; stefania.nottola@uniroma1.it \\ 3 Department of Anatomical Sciences, Faculty of Medical Sciences, Tarbiat Modares University, \\ Tehran 1411713116, Iran; ihalvaei@modares.ac.ir \\ 4 San Raffaele Scientific Institute, IVF Unit, Department OB/GYN, Vita-Salute University, 20132 Milan, Italy; \\ desantis.lucia@hsr.it \\ * Correspondence: sandra.cecconi@univaq.it; Tel.: +39-0862-433459 \\ + These authors contribute equally.
}

Received: 1 March 2019; Accepted: 9 April 2019; Published: 13 April 2019

check for updates

\begin{abstract}
Women affected by ovarian pathologies or with cancer can usually preserve fertility by egg/embryo freezing. When oocyte retrieval is not feasible, the only option available is ovarian tissue cryopreservation and transplantation. The culture of follicles isolated from fresh or cryopreserved ovaries is considered still experimental, although this procedure is considered safer, because the risk of unintentional spreading of cancer cells eventually present in cryopreserved tissue is avoided. Animal and human small follicles can be cultured in vitro, but standardized protocols able to produce in vitro grown oocytes with the same developmental capacity of in vivo grown oocytes are not available yet. In fact, the different sizes of follicles and oocytes, the hormonal differences existing between mono(e.g., human, goat, cow, and sheep) and poly-ovulatory (rodents and pig) species, and the incomplete identification of the mechanisms regulating the oocyte-follicle and follicle-ovary interrelationships affect the outcome of in vitro culture. From all these attempts, however, new ideas arise, and the goal of assuring the preservation of female reproductive potential appears a more realistic possibility. This review surveys and discusses advances and challenges of these technologies that, starting from a simple attempt, are now approaching the biosynthesis of a functional engineered ovary.
\end{abstract}

Keywords: mammals; ovary; follicle; oocyte; developmental competence; cancer; in vitro culture; 3D bioprinting; bio-scaffolds

\section{Introduction}

\subsection{Infertility: What Is It?}

What is the meaning of the term "infertility"? According to the most recent literature, infertility corresponds to the failure to achieve a clinical pregnancy after 12 months (women $<35$ years) or after 6 months (women $>35$ years) of regular unprotected sexual intercourse. It affects $8-12 \%$ of reproductive-aged couples worldwide, a percentage that may even increase up to $25 \%$ for couples living in Western Countries [1-3]. The terms infertility and subfertility can be used interchangeably, although subfertility more generally addresses any form or grade of reduced fertility. Infertility may be classified as primary (difficulties to conceive at all) or secondary (difficulties to conceive the desired number of children) [1]. In the female, infertility should be differentiated from impairment of 
fecundity, which includes either frank infertility or difficulty of carrying a pregnancy to term (recurrent implantation failure) [3,4]. While infertility may be limited to a period of time, sterility corresponds to a permanent state of infertility [2].

\subsection{Main Causes of Infertility in the Female}

Often (25-50\% of cases), female infertility is related to anovulation [1]. However, different conditions-affecting the single individual, the couple or the environment are claimed to be responsible or contribute to some extent to the establishment of a full-blown condition of infertility.

\subsubsection{Disease-Related Infertility}

Premature ovarian insufficiency (POI), polycystic ovary syndrome (PCOS) and endometriosis may all play a role in inducing female infertility [2]. In addition, treatments for cancer and other systemic pathologies are very important determinants of female infertility due to their high gonadotoxic potential. In detail, POI occurs in about $1 \%$ of women. It is defined as the cessation of menstrual cycles in women younger than 40 years of age in the presence of an elevated serum Follicle Stimulating Hormone (FSH). The causes of POI may be genetic (Turner's syndrome, in particular), environmental, infective or metabolic. Other forms of POI are associated with autoimmune conditions, or may have a-iatrogenic origin, occurring as a consequence of surgical interventions or cancer treatments (see below). Inflammatory aging, an intriguing process that induces inflammatory reactions in various tissues and organs, may also play a role in the pathogenesis of POI [5]. However, in the majority of cases, the origin of POI remains unknown [2]. Instead, PCOS is an endocrine disorder affecting $5-10 \%$ of the female population. It is a heterogeneous condition characterized by ovulation impairment, a typical ultrasound morphology, and hyperandrogenism [6]. Socioeconomic status, lifestyle, cultural factors and race may influence PCOS determinants and variations in phenotype [2]. PCOS is also frequently associated with obesity. Obese women affected by PCOS may show even more severe metabolic and reproductive alterations than the not obese counterpart [7]. Endometriosis is a pathological pelvic inflammatory process usually associated with infertility. Endometriosis-related infertility may be due to anatomical alterations of the female genital tract in presence of adhesions and fibrosis; endocrine and/or immunological alterations may also contribute to impairment of fertility in women of reproductive age affected by endometriosis. Even if fertilization occurs, embryo implantation may be affected in the presence of endometriotic lesions [2]. The strict relation between endometriosis and infertility is proven as well by the fact that, if lesions are removed, the condition of infertility may undergo reversal [8].

\subsubsection{Cancer and Anticancer Treatments}

Cancer per se does not seem to impair fertility. Very encouraging results in fact reveal that, in young women with malignancies, ovarian reserve, response to gonadotropins, number and quality of oocytes retrieved for in vitro fertilization (IVF) in the field of fertility preservation (see below) remain unaffected by the neoplastic process $[9,10]$. On the other hand, aggressive anticancer treatments such as chemotherapy and radiotherapy may have massive gonadotoxic side effects, leading to iatrogenic loss of fertility in treated women [11]. In detail, more than 35,000 women between 15 and 39 years of age are diagnosed with cancer every year. Advances in cancer treatments lead the majority of them to survive, but the risk of transient or permanent infertility represents a long-term complication of the treatment, often affecting the quality of life of cancer survivors, in which the decrease of the likelihood of having biological children represents a source of high distress [12]. The extent of toxicity depends on patient's age and the type of chemotherapy applied. However, all anticancer treatments should be considered gonadotoxic, since they can not only induce POI but can even reduce the reproductive window of the patient [13]. Other disease-related forms of infertility are represented by hypogonadotropic hypogonadism, disorders of ciliary function and cystic fibrosis. Infertility is also frequently associated 
to reproductive tract infections [2]. Different endocrine pathologies, such as hypothalamic, pituitary, thyroid, adrenal, and ovarian disorders, may impair fertility as well [1].

\subsubsection{Age-Related Infertility}

Reproductive aging is a process physiologically occurring in every woman and ultimately leading to reproductive senescence and menopause. As a woman gets older, an evident decrease in fecundity occurs in parallel, due to both a reduction of the ovarian follicle numbers and an impairment of oocyte quality as well. In particular, by age 35 a woman's chance of conceiving per month is decreased by half and, at the age of 45 , the natural fertility rate per month drops to $1 \%$ [14]. Thus, postponing motherhood for social, educational or financial reasons may significantly decrease the chance for a woman to become pregnant and/or increase the risk of obstetric complications [15]. However, despite such a well-known impairment of fecundity, reproductive aged women frequently understate the age at which such a decline occurs and, reverse, overestimate the performances of assisted reproductive technologies (ART) in circumventing age-related infertility [16].

\subsubsection{Environment-Related Infertility}

Air pollution has been nowadays clearly put in relation with some forms of cancer and with cardiovascular and respiratory disease as well. Air pollutants could also act as endocrine disruptors, being direct or indirect causes of infertility in female population, although further studies are needed to better clarify this possible connection [17]. Environmental chemicals present in water and food could also affect female reproduction. Bisphenol, primarily used in the production of polycarbonate plastics, and phthalate plasticizers, for example, may affect ovarian functions and pregnancy, leading to infertility [18]. Pesticides may also exert a pivotal role in compromising female infertility. For example, mancozeb and lindane, two endocrine disruptors widely used in agriculture, are able to dramatically jeopardize the production of fertilizable oocytes [19-23].

\subsubsection{Lifestyle-Related Infertility}

A very wide range of lifestyle-related factors, including various forms of addiction (excessive/altered consumption of food, alcohol, cigarette smoke and drugs) may also affect not only the general quality of life but even the fertility status of an individual [2].

\subsection{Strategies for Contrasting Infertility in the Female}

According to what has previously been reported, clinicians, biologists and, in general, healthcare professionals facing infertility problems have firstly to take into consideration that this pathology is multifactorial and strongly influenced by clinical condition, treatments, age, environmental factors and lifestyle. Thus, prevention of infertility is the first step to cope with. To prevent infertility, improvement in the lifestyle, early diagnosis and proper treatment of the primary pathology eventually leading to infertility are needed $[5,6,8]$. Taken together, all these items could be collected under the term "ecofertility" [24]. Another approach finalized to limit infertility problems in young women is the preservation of fertility. Fertility preservation is an emerging field that offers treatments aimed to protect future reproductive ability for individuals at risk to lose their reproductive potential, particularly useful for oncologic patients subjected to gonadotoxic therapies for cancer treatment. For these individuals, cancer treatment can be lifesaving (up to $80 \%$ of survivors) but can permanently affect reproductive capacity $[12,13,25]$. Oncofertility, therefore, is a term currently used to describe the support of fertility preservation to patients with cancer, exerted through storage of gametes, embryos or gonadal tissues for later use. Different options are in fact offered to female patients undergoing cancer therapy, according to their age and partner status. In particular, oocyte or embryo cryopreservation before chemotherapy or radiation are the most frequently adopted strategies in the field of fertility preservation. However, these options cannot be used in prepubertal patients, or in reproductive age women for which ovarian stimulation, usually performed to obtain a larger number of oocytes to be stored or subjected to IVF, 
should be avoided because it would interfere with the patient's treatment plan [25]. Other options are offered to these patients, i.e., the cryopreservation of either whole ovary or cortical fragments (strips) of the ovarian tissue followed by transplantation [26]. Frozen-thawed ovarian cortical fragments can be also subjected to in vitro culture, inducing follicular development in vitro (in vitro growth, IVG) and finally achieving oocyte maturation from immature (germinal vesicle stage, GV) to fully mature (metaphase II, MII) stage (in vitro maturation, IVM) [25,27-32]. According to such a wide range of therapeutic options today available for approaching the treatment of different forms of infertility, the specific aims of this paper are to review the most recent opportunities to obtain oocytes suitable for fertilization by various in vitro technologies. However, before going through this subject, it is important to remind how mature oocytes are physiologically produced, because the complexity of this process allows understanding how difficult is to obtain them in vitro.

\section{The Production of Fertilizable Oocytes}

\subsection{Folliculogenesis}

Folliculogenesis is defined as the sequence of processes that allow the formation of a mature ovarian follicle, containing a fertilizable oocyte (Figure 1).

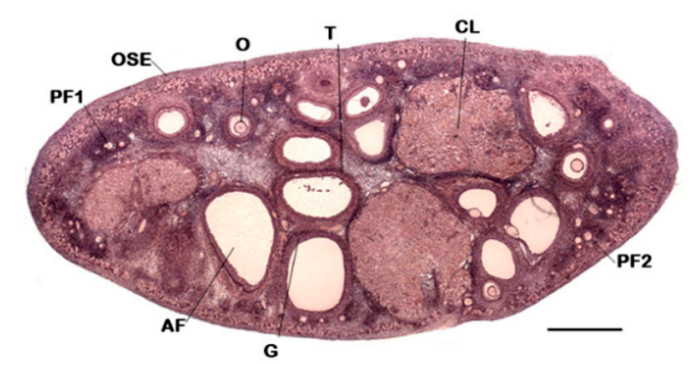

Figure 1. A mammalian ovary. Panoramic view of a mouse ovary by light microscopy. Follicles at various stages of development are shown. Follicles become responsive to FSH from the secondary stage onward. In these follicles, estrogen production increases. Mid-cycle Luteinizing Hormone (LH) surge induces oocyte meiotic resumption and the ovulated oocyte is arrested at MII. The $\mathrm{CL}$ originates from cells of the follicle wall during ovulation, although its precise origin remains controversial. Abbreviations: PF1 (primordial follicle); PF2 (primary follicle); AF (antral follicle); O (oocyte); G (granulosa cells); T (theca cells); OSE (ovarian surface epithelium); CL (corpus luteum). Bar $=1 \mathrm{~mm}$.

It is noteworthy that folliculogenesis fails to produce a large number of mature follicles due to the occurrence of an apoptotic related process (atresia) that naturally reduces the original number of follicles of more than $99 \%$. It has been calculated that in a woman half of the about 7 million of oocytes that are likely produced during embryo and fetal development are eliminated before birth. At the onset of puberty, the about 2 million healthy follicles present in the human ovary at birth are reduced to about 300,000 . As this loss continues up to menopause, women throughout their fertile life can produce about 400 healthy mature oocytes. Conversely, sperm production usually keeps up throughout the entire life, and sperm treatments, such as those aimed to enhance motility, do not affect embryo quality $[33,34]$. Furthermore, the presence of spermatogonial stem cells allows recovery of fertility also after chemotherapy [35].

The precursors of oocytes are Primordial Germ cells (PGC). PGC actively proliferate during their migration towards the genital ridges under the control of several transcription factors [36]. In the gonads, proliferating PGC have incomplete cytokinesis, evidenced by intracellular bridges [37]. After leaving mitosis and entering meiosis, PGC remain arrested at diplotene of the first meiotic division, commonly known as GV stage. This transition occurs during the first days after birth in mice and during fetal life in domestic animals and primates. Now, a single layer of flattened pre-granulosa cells (pre-GC) 
surrounds the oocyte to form the primordial follicle. In rodents, follicle formation occurs during the first few days after birth, while in primates during fetal life. The primary oocytes are arrested at diplotene of prophase I for a long period of time (resting stage), which lasts months in rodents and years in humans [38]. Despite the presence of mitotically active germ cells inside the mammalian ovary [39,40], the number of oocytes is fixed early in life, and neo-oogenesis is excluded [41]. Periodically, a cohort of primordial follicles is recruited into growth phase (activation), evidenced by the transition from flattened to proliferating cuboidal GC (Figure 1) [42,43]. Little is still known about the molecules driving the exit from resting to growth phase. Follicular growth is controlled by local factors and not by gonadotropins [42,44]. The accurate balancing of activatory (e.g., Anti-Mullerian hormone, AMH [45]) and inhibitory (e.g., Spermatogenesis- and oogenesis-specific basic helix-loop-helix-containing protein 2, Sohlh2; and Phosphatase and tensin homolog, PTEN [46]) factors avoids premature exhaustion of primordial follicle pool, with consequent reproductive senescence in animals or menopause in humans. As soon as follicles enter the growth phase and become bilaminar (secondary), GC undergo a differentiation process by which they acquire responsiveness to FSH [43,47,48]. Although FSH receptors are present on the GC, FSH is not required up to preantral-to-antral transition [49,50]. However, FSH may affect the size of primordial follicles and population of early secondary follicles, which challenges the gonadotropin-independent theory regarding the early folliculogenesis [51,52]. As soon as follicles start growing, theca cells (TC) are recruited from surrounding stroma to form two distinct layers: internal theca, which secretes androgens, and externa theca, which contains smooth muscle cells and collagen fibers (Figure 1) [43]. The formation of TC layers is regulated by both the oocyte (via the production of growth differentiation factor-9, GDF-9, a member of the transforming growth factor $\beta, T G F \beta$, superfamily), and GC (via the production of Kit ligand, KL). Concomitantly with theca formation, receptors for Luteinizing Hormone (LH) becomes detectable [53]. The establishment of a complex regulative network between oocyte, GC and TC requires either the formation of gap junctions or the production of regulative paracrine factors and is fundamental to control whole folliculogenesis and fertility [54,55]. GC produce activins and inhibins, which regulate not only GC differentiation but also oocyte maturation and androgens synthesis by TC [56,57]. In addition, the oocyte increases in size, and secretes the glycoproteins of zona pellucida (ZP), an extracellular matrix that will play a key role in the block of polyspermy after fertilization. The contribution of follicle cells to the production of zona components is species-specific. While mouse oocytes are capable of synthesizing all zona proteins [58], in humans or large mammals, both the oocyte and the follicle cells contribute to their synthesis [59]. The transition from secondary to antral stage is characterized by the FSH-dependent appearance of a fluid-filled cavity, the antrum, which determines the differentiation of GC into two distinct populations, the cumulus cells (CC) and the mural GC (MGC). These cells have not only a different morphology, but also different functions and gene expression [53]. The final steps of development are completed by few "privileged" follicles, selected in the pool of growing ones. This phenomenon is called dominance. A dominant follicle has more GC compared to other follicles and produces more estradiol (E2) to induce negative feedback on FSH secretion [60]. Consequently, when FSH secretion decreases, only the dominant follicle(s) survive. Recently, some microRNAs (miR), such as miR-144, miR-202 and miR-873, have been found to be upregulated in healthy follicles in comparison with atretic ones [61]. The mature (Graafian) follicle has reached the max size (in humans $>10 \mathrm{~mm}$ ), and the enclosed GV-stage oocytes has reached its final diameter (about $120 \mu \mathrm{m}$ for humans).

\subsection{Oocyte Maturation}

At puberty, the fully-grown GV-arrested oocytes enclosed in preovulatory Graafian follicles can resume meiosis in response to LH surge (Figure 2a). The molecular mechanisms regulating meiotic resumption has been recently elucidated. As above reported, FSH stimulates the production and expression of E2 and estrogen receptors (ERs) which, in turn, upregulate the expression levels of an inhibitory signal, natriuretic peptide precursor C (NPPC or CNP), produced in MGC. The binding of NPPC to its receptor, natriuretic peptide receptor 2 (NPR2), in CC stimulates the production of cyclic 
guanosine monophosphate (cGMP), which diffuses via gap junctions into the oocyte. Since meiotic arrest is ensured by a high intraoocyte concentration of cyclic adenosine monophosphate (cAMP), the cGMP-dependent inhibition of phosphodiesterase 3A (PDE3A) activity in the oocyte maintains the GV stage. Conversely, preovulatory LH surge downregulates ER and, as a consequence, the decrease of NPPC and NPR2 levels triggers oocyte meiotic resumption [62]. In addition, CC-dependent secretion of a hyaluronan-rich matrix facilitates the uncoupling of the cumulus-oocyte contacts (cumulus expansion). The activation of maturation promoting factor (MPF) and mitogen-activated protein kinase (MAPK) signaling pathways drive the formation of the first meiotic spindle (metaphase I, MI) and the extrusion of the first polar body $(\mathrm{PB})$ with the redundant genetic material. After that, the second meiotic division starts but arrests at MII stage with the formation of the second meiotic spindle (Figure 2b). The release of the cumulus-oocyte complex containing MII oocyte is known as ovulation and requires the rupture of follicular wall [63]. During nuclear maturation, which lasts several hours in mammals ( $12 \mathrm{~h}$ in mice and $24 \mathrm{~h}$ in humans), the oocyte undergoes cytoplasmic changes evidenced by the rearrangement of mitochondria and cytoplasmic membranes, migration of cortical granules towards the subplasmalemmal areas, to assure the block of polyspermy through the cortical reaction. Both nuclear and cytoplasmic maturation are necessary for being competent for fertilization and producing a viable embryo. The somatic cells of the ovarian follicle differentiate to corpus luteum, which secrete progesterone $(\mathrm{P})$ to prepare the endometrium for implantation [53]. After fertilization, the second meiosis is completed by extrusion of the second PB [64].
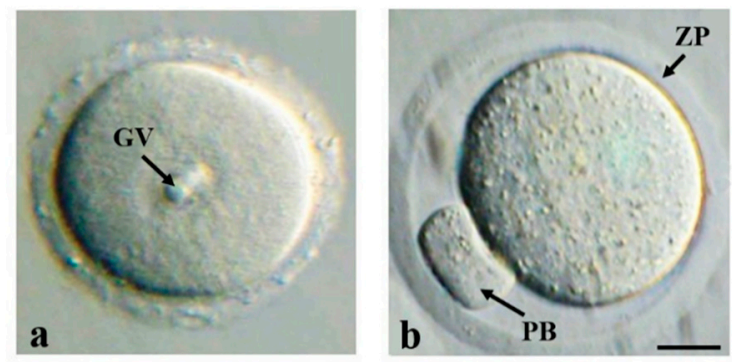

Figure 2. Fully grown mouse oocytes. (a) GV stage. To show the GV, surrounding cumulus cells have been mechanically removed. (b) MII stage. Expanded cumulus cells have been removed to evidence PB. Abbreviations: GV (germinal vesicle); ZP (zona pellucida); PB (polar body). Bar $=20 \mu \mathrm{m}$.

\section{Methods for Obtaining Fertilizable Oocytes from In Vitro Grown (IVG) Mammalian Follicles}

The culture in vitro of mammalian follicles allows fertility preservation without the risk of cancer reimplantation following the transplantation of ovarian cortical tissue [65]. Starting from the consideration that an in vitro culture system has to assure the production of competent oocytes by reproducing the unique features of the in vivo grown follicles, several protocols have been developed during these years, with discrepant results depending on the species studied. The main factors affecting outcome of in vitro culture are the age of patients (prepuberal and adult), the type of culture (isolated follicles, and organ culture with or without biomatrices and scaffolds), culture conditions (length and supplements) and the occurrence of uncontrolled epigenetic modifications.

\section{$2 D$ and 3D Culture Systems}

2D (non-spherical) and 3D (spherical) culture systems have been established to culture secondary and primary/primordial follicles. The latter are usually preferred because able to better survive to chemotherapy and cryopreservation, although they must be cultured inside ovarian cortical strips to avoid massive apoptosis.

In the 2D approach, the surface of a dish or membrane is coated with one or more components of extracellular matrix (ECM), which provide structural support for the maintenance of efficient intercellular communications, proper cell differentiation and survival. The mouse was the first selected 
model, because of shorter folliculogenesis and more knowledge about the molecular mechanisms controlling the production of developmentally competent oocytes. The first IVG oocytes able to produce some blastocysts were obtained by Eppig and Schroeder, in 1989 [66]. A few years later, a two-step method based on the combination of ovarian tissue and 2D culture onto collagen gels allowed obtaining the first viable offspring from IVG activated primordial/primary mouse follicles [44]. Since the development of multistep culture systems better supports each specific developmental stage [67], after several technical improvements, mouse primordial follicles were completely differentiated in vitro. The derived embryos were able to produce a healthy colony formed by 35 females and 37 males that survived to adulthood [68]. Similar results were obtained by others, either by culturing cryopreserved follicles [69] or by simply modifying the culture protocols [70]. However, gene expression, reactive oxygen species (ROS) production, steroid secretion and mitochondria activity of IVG follicles appear altered in comparison with in vivo follicles [71]. Despite these limits, mouse systems provided useful information for the culture of preantral follicles from large mammals and humans [72]. The first IVG ovine follicles were obtained by a 2D system, although the enclosed oocytes were far from full developmental competence [73-75]. Beside the disruption of intercellular communications, the altered expression of several key genes, such as those regulating steroid synthesis and apoptosis, can account for reduced in vitro development [76]. Surprisingly, the methylation profile of three imprinted genes and developmental competence were comparable to that of oocytes obtained in vivo from the early antral follicles [77].

The 3D culture systems more closely mimic the physiological environment of the ovary. The encapsulation of follicles in various substrates as alginate gels, collagen or Matrigel ${ }^{\circledR}$ determines a better preservation of follicle 3D architecture and of functional communications between somatic and germ cells. Matrigel ${ }^{\circledR}$ is a basement membrane rich in ECM components and growth factors; alginate is a natural biopolymer obtained from brown algae and characterized by high biocompatibility, structural similarity to ECM and capable to form a gel with well-defined features [78]. At present, many researchers consider alginate as the best support capable of assuring the production of live offspring [79]. Despite the technical difficulties experienced in isolation and encapsulation of follicles, alginate system has allowed the successful culture of follicles from dog, goat, baboon and macaque [80] (Figure 3). More recently, Higuchi [81] proposed a simplified procedure by which mouse preantral follicles can be easily cultured into a solid Matrigel ${ }^{\circledR}$ drop supported on a membrane. After 10 days culture, the thick Matrigel ${ }^{\circledR}$ drop yielded a high percentage of mature oocytes and the production of five pups from 80 transferred embryos.

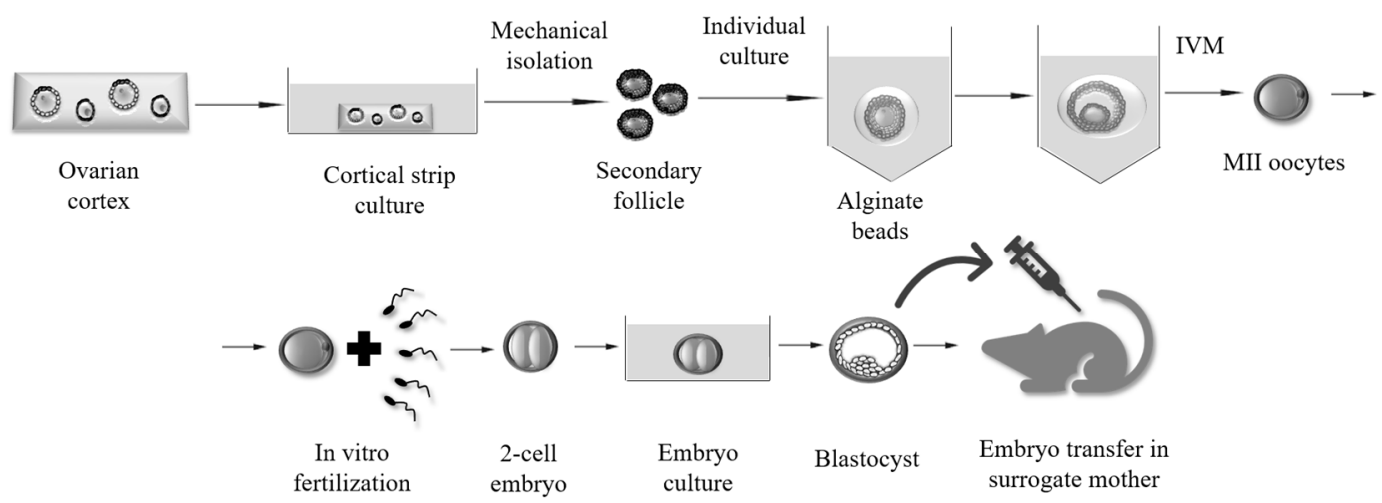

Figure 3. Schematic representation of multi-step culture. Primordial follicles are cultured in ovarian cortex to antral stage. Preovulatory oocytes undergo in vitro maturation (IVM). Metaphase II oocytes (MII) are in vitro fertilized and embryos transferred to surrogate mothers.

Concerning humans, in 1999, two groups of researchers [82,83] were able to grow follicles in cortical slices instead of isolating them. The studies revealed two unexpected findings: (i) the presence of ovarian cortical fragments facilitated follicle development; and (ii) the activation of primordial 
follicles was dependent on ovarian microenvironment and not on gonadotropins as believed until that time. Many attempts and years later, in 2008, Telfer et al. [84], by using a two-step culture system, obtained a human antral follicle from primordial follicles. These follicles were firstly cultured into pieces of ovarian cortical tissue up to secondary stage and then, following their isolation, onto a membrane up to antral stage. The problem of uncontrolled primordial follicle activation was solved by treating human ovarian cortex exposed to inhibitors of an enzyme (PTEN), a stimulator of apoptosis, before xenografting under the kidney capsule of severely compromised immune-deficient (SCID) mice [85]. The downregulation of Hippo signaling, followed by auto-grafting of ovarian fragments under the serosa of fallopian tubes, has enhanced primordial follicle survival in a patient with premature menopause, and has allowed this woman to generate a live birth [86]. However, recently, Maidarti and collaborators found that non-growing bovine follicles exposed during tissue culture to a specific inhibitor of PTEN showed increased DNA damage and a significant reduction of DNA repair response either in oocytes and somatic cells [87]. Recently, encapsulation of strips of human cortical ovarian tissue within alginate gels resulted in the production of the first antral follicle after a six-week culture [88], while several MII arrested oocytes were obtained by culturing alginate-encapsulated follicles [89]. In 2018, Telfer and her collaborators [90] obtained for the first time MII oocytes from human unilaminar follicles by using a four-step culture system. After that, reproducible results have been achieved by several laboratories using fresh and cryopreserved ovarian tissue, and new information about the genes regulating this process is now available (for a review, see [67]).

\section{Focus on the Ultrastructural of 2D Ovarian Follicles}

Despite the many reports on culture systems, very few reports on the ultrastructural morphology of IVG follicles are present. According to this premise, if we try to conjugate specific culture systems with the in vitro behavior of growing mouse ovarian follicles evaluated by their structural and ultrastructural morphology, we can depict by light, scanning and transmission electron microscopy (SEM and TEM) very interesting features.

By comparing in vivo grown (Figure $4 \mathrm{a}, \mathrm{b}$ ) and IVG mouse follicles cultured in a 2D system with FSH, we noted that most FSH-treated follicles formed in vitro the antral cavity (Figure 4c,d) and showed various other ultrastructural markers of maturity (spreading of organelles in ooplasm, some granulosa cell-oolemma contacts, and granulosa cell proliferation). However, even if FSH supports the in vitro growth of follicles, the presence of a diffuse granulosa cell-oocyte uncoupling and the absence of theca development reveal the incomplete efficiency of the system [30].

As seen by SEM, FSH has also been demonstrated to exert an antiapoptotic action on granulosa cells via stimulation of the hyaluronan synthesis in an in vitro co-culture system in which pig granulosa cell multilayers have been used with cumulus-oocyte complexes (COCs) anchored on them [91]. The pro-survival effect of FSH on porcine granulosa cells in a co-culture system appears to be even enhanced if epidermal growth factor (EGF) is added to the culture [92]. Among growth factors, insulin-like growth factor 1 (IGF-1) also improves IVG of bovine preantral follicles [93]. On the contrary, the addition of tumor necrosis factor (TNF)- $\alpha$ to a six-day culture of bovine ovarian follicles reduces follicle survival and increases the number of apoptotic cells in the ovarian tissue, while the presence of dexamethasone maintains follicle ultrastructure in cultured tissue [94]. In other monovular mammals such as ovine, age or-better-sexual maturity at sampling also seems to influence in vitro full maturation of COCs, as evidenced by a comparative ultrastructural analysis performed by TEM on prepubertal and adult COCs $[95,96]$. Thus, it is important to highlight not only the crucial role exerted by studies on animal models in defining an "ideal" culture system for human ovarian follicles, but also the importance of morphological ultrastructural evidences in this field. 


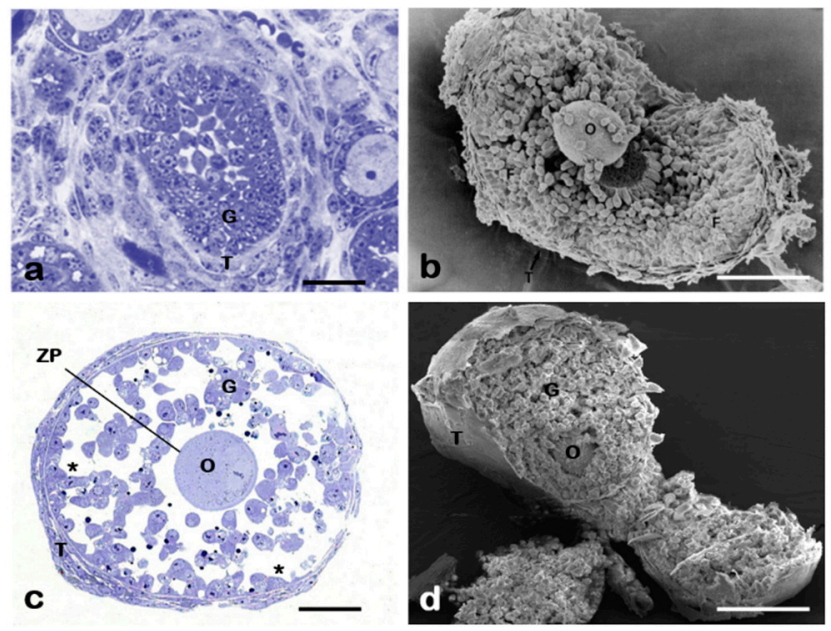

Figure 4. General appearance of in vivo $(\mathbf{a}, \mathbf{b})$ and in vitro grown (IVG) (c,d) mouse follicles, the latter cultured in a 2D system up to antral stage under: $(\mathbf{a}, \mathbf{c})$ light microscopy; and $(\mathbf{b}, \mathbf{d})$ scanning electron microscopy. (a) The oocyte is not visible due to the plan of section, which is not equatorial. Abbreviations: O (oocyte); ZP (zona pellucida); G (granulosa cells); T (theca cells); asterisks: fluid-filled spaces (antrum). Bar $=50 \mu \mathrm{m}(\mathbf{a}, \mathbf{c}) ; 100 \mu \mathrm{m}(\mathbf{b}, \mathbf{d})$. Modified from: Macchiarelli et al. (1992) [43] (b) and Nottola et al. (2011) [30] (c,d), with permission.

\section{Towards a Biosynthetic Mammalian Ovary}

\section{1. $3 D$ Bioprinting}

The lack of tissue/organ transplants is one of the leading causes of death: in Europe, every day 18 people on waiting lists die waiting for a transplanted organ [97]. Printing human organs/tissues is an excellent alternative for a large-scale manufacture of engineered tissue/organ with therapeutic value. $3 \mathrm{D}$ printing requires the combination of engineering, cell biology, biomaterial technology, medical imaging (X-ray, computed tomography, magnetic resonance imaging, and ultrasound imaging) and medicine. The understanding of specific arrangements of functional and supporting cells, the structure and composition of ECM, the presence and dosage of soluble/insoluble factors is mandatory for the replication of biological tissues [98].

A typical process for bioprinting is based on acquisition of raw data followed by a $3 \mathrm{D}$ anatomical representation of the organ/tissue, also with eventually damaged areas. Then, the 3D rendered model can be divided into 2D slices that are imported into specific bioprinter systems. Deposition and patterning of biological materials utilized inkjet, microextrusion and laser-assisted printing (for more details, see $[98,99]$ ). There are four parameters to consider while 3D printing viable human tissues: resolution, speed, complexity and biocompatibility. High resolution is critical for designing whole organ structure, capillaries and microcellular elements; speed allows retaining a proper physiological/differentiative stage and a high survival time of all the cell types utilized to "build" the new organ/tissue. By the combination of speed, resolution and biocompatibility, it is possible to achieve the complex vasculature network and scaffolding needed for a human tissue to survive once transplanted into living organisms.

Good strategies are to replicate a tissue on a microscale, or to replicate it according to the genesis and subsequent differentiation of embryonic organs. In the former procedure, each organ/tissue can be considered formed by "building blocks" or mini-units, usually corresponding to the smallest structural and functional component of a tissue/organ (Langerhans islets, nephrons, etc.). Then, mini-units can be assembled by rational design, by cell self-assembly capacity, or both. For example, "organs-on-a chip" are used to reproduce models of disease or for the screening of toxicants $[100,101]$. In the latter, the knowledge of the developmental mechanisms regulating organogenesis allows following step-by-step the composition, localization, functional and structural properties of the tissue. 


\subsection{The New Ovaries}

The possibility to use fibrin gel, formed by high concentration of fibrin and thrombin, as scaffold was tested by Amorin and her colleagues in 2016 [102]. They recovered human primordial and primary follicles that were encapsulated into fibrin clots before being xenotransplanted into nude mice. The grafted follicles were viable and increased in size.

In 2017, Laronda and colleagues [103] published the possibility of creating a mouse bioprosthetic ovary capable of restoring ovarian functions in sterilized animals. If compared with the encapsulation within hydrogels (Figure 5a), now the strategy is to produce a structure capable of assuring not only follicle growth but also long-term function of the bioconstruct after transplantation. Therefore, the authors focused particular attention on scaffold printing (Figure 5b), because it was necessary to obtain scaffold designs with similar struts (about $250 \mu \mathrm{m}$ ) and distance between struts (about $350 \mu \mathrm{m}$ ) to reproduce a defined micropore architecture, that assures follicle development. By using a 3D printable gelatin, they formed a hydrogel scaffolds with optimized pore geometry either to seed follicles or to allow nutrient diffusion. They reported that maintenance of follicle's spherical shape required scaffolds with corners surrounding follicles on multiple sides but with limited follicle-scaffold interactions. Follicles cultured for eight days expressed laminin, thus confirming the formation of a basal lamina, and produced steroids. The enclosed oocytes reached normal final diameters and were able to complete meiotic maturation up to MII stage and to ovulate. These scaffolds can be implanted without undergoing enzymatic degradation, as required when follicles are encapsulated in gels. When implanted into ovarian bursa of ovariectomized mice, scaffolds were vascularized within few days, showing a distribution and density of vessels comparable to that recorded in normal ovaries. It is remarkable that the lack of any mechanical manipulation better preserves oocyte quality. In fact, after mating and without any hormonal supplementation, recipients with bioprosthetic ovarian fragments produced healthy litters that are nursed because of normal prolactin production. This indicates that following xenografting a normal hypothalamic-pituitary-ovarian axis is well re-established.

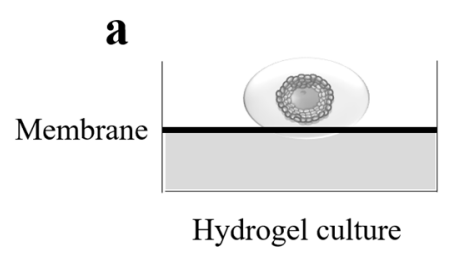

b

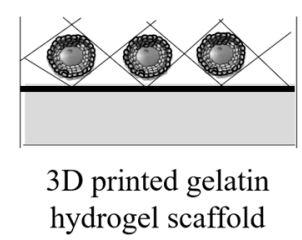

c

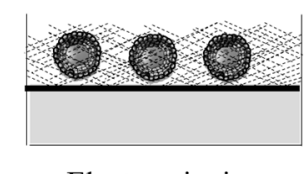

Electrospinning

Figure 5. Comparison of the experimental design used to in vitro culture of secondary follicles. (a) Isolated secondary follicles are transferred in drops of hydrogels (alginate-Matrigel ${ }^{\circledR}$ ) on a polypropylene mesh $(100 \mu \mathrm{m})$. Then, the mesh is immerged into encapsulation solution. (b) Bioprinted scaffold (gelatin) has struts of $\sim 350 \mu \mathrm{m}$ and pore size of $\sim 350 \mu \mathrm{m}$; angles are $30^{\circ}$ or $60^{\circ}$. Secondary follicles are seeded onto scaffold and cultured. Contacts with scaffold and follicles are limited. (c) Electrospinning technique produces fibrous scaffold of poly ( $\varepsilon$-caprolactone) and gelatin. Average fiber diameter: $495 \pm 133 \mu \mathrm{m}$. Follicles are adherent on the entire bio-structure.

More recently, three new approaches have been reported in the literature. The first is based on the decellularization of human ovary. In fact, by using sodium lauryl ester sulfate (SLES), organ-specific extracellular matrix-based scaffolds have been used as a native niche for the culture of primary ovarian cells (POC) obtained from human ovaries. These cells show a surprising capability to reconstruct primordial or primary follicle-like structures within the scaffolds. This innovative approach has been validated by in vivo studies that confirm biocompatibility, normal steroid production and neovascularization [104]. In the second, innovative fibrous scaffolds (average diameter: $495 \pm 133 \mu \mathrm{m}$ ) have been produced by electrospinning of poly ( $\varepsilon$-caprolactone) (PCL) and PCL/gelatin, which reproduce a structure similar to the ovarian healthy tissue. PCL is a biodegradable polyester that, when blended with gelatin, improves strongly scaffold biocompatibility while reducing biodegradability. 
It has been found that porcine follicles can adhere on the entire surface and not only where cells and scaffold are in contact with struts (Figure 5c). Porcine follicles showed high viability and good morphology after a 10 days-culture, while oocyte quality needs to be assessed [105]. The third has been recently published by Antonino and colleagues [106], who cultured bovine preantral follicles in a 3D levitation system based on the utilization of magnetic nanoparticles. Briefly, follicles were individually incubated in microtubes with culture medium and nanoparticles, and then transferred to a 24-well plate covered with a lid insert and a magnetic drive to allow levitation after $1 \mathrm{~h}$ of magnetic treatment and cultured for 16 days. Results seem very promising in terms of high proportion of viable and meiotic competent oocytes.

\section{Conclusions and Future Perspectives}

Despite the undeniable progresses, protocols for in vitro growth of ovarian follicles from fresh or cryopreserved ovarian tissue fragments have not been optimized thus far. Technical modifications need to be confirmed at morphological and molecular levels, because it is mandatory to determine whether IVG oocytes are actually "normal". It is evident that all these culture systems have some limitations, and the acquisition of full oocyte developmental competence, that is complete nuclear-cytoplasmic-epigenetic maturation, is not achieved yet. Many hormones and growth factors, such as FSH, insulin, EGF, selenium and transferrin, are commonly used for in vitro culture but it is difficult to balance the concentration of each supplement to sustain viability, growth and competence, especially for animal models other than mice $[107,108]$. For example, FSH deprivation decreases survival rate in macaque preantral follicles and cannot be compensated by estrogen and androgen supplementation [109]. Recently, Jones and Shikanov [110] published an interesting review focused on the paracrine and autocrine signaling controlling whole follicle development in vitro. Altogether, these data point out that it is necessary to optimize protocols before transferring them to clinical use.

The availability of clinical practice guidelines on fertility preservation care represents an important goal [111], although several clinical, socioeconomic, legal, ethical and religious barriers limit oncofertility practice worldwide [112]. Appropriate counseling by physicians and oncologists, in particular, is still inadequate in several countries [11]. To date, only two networks exist, the FertiPROTEKT [113] and Oncoferility Consortium [114]. The first links fertility centers in all German-speaking countries (Germany, Austria and Switzerland), while the second involves fertility preservation centers in USA and worldwide [11,112]. Precise indications from ethical committees-even if ethical laws may differ from one country to another-may be crucial for a wider and safer application of fertility preservation protocols [115]. Nowadays, there is also an emerging demand for fertility preservation treatments from women who, under the pressure of various society rules, decide to postpone their motherhood to an age after which a significant decline in fertility occurs. In such a dynamic scenario, Hikabe and colleagues obtained in 2016 [109] the successful production of fully viable mouse offspring by culturing in vitro either embryonic stem cells or induced pluripotent stem cells (iPSC) derived from both embryonic fibroblasts and adult tail tip fibroblasts [116]. For the first time, the entire mouse reproductive cycle has been reproduced in a simple culture dish. We do not know if this will occur also for humans. The production in vitro of a healthy person requires the ability to mimic an extraordinarily complex network of genes and proteins able to induce controlled tissue and cell-specific expression that act in a temporally regulated manner and are dependent on each other, strongly influenced by the environment and exogenous agents. To reproduce it in a dish could represent a true challenge.

Author Contributions: Conceptualization, S.C., G.M., S.A.N., L.D.S., G.R., V.D.N. and I.H.; and writing-original draft preparation, G.R. and V.D.N.

Funding: This research received no external funding.

Conflicts of Interest: The authors declare no conflict of interest. The funders had no role in the design of the study; in the collection, analyses or interpretation of data; in the writing of the manuscript or in the decision to publish the results. 


\section{References}

1. Weiss, R.V.; Clapauch, R. Female infertility of endocrine origin. Arq. Bras. Endocrinol. Metabol. 2014, 58, 144-152. [CrossRef] [PubMed]

2. Vander Borght, M.; Wyns, C. Fertility and infertility: Definition and epidemiology. Clin. Biochem. 2018, 62, 2-10. [CrossRef] [PubMed]

3. Gaskins, A.J.; Chavarro, J.E. Diet and fertility: A review. Am. J. Obstet. Gynecol. 2018, 218, 379-389. [CrossRef]

4. Bashiri, A.; Halper, K.I.; Orvieto, R. Recurrent Implantation Failure-update overview on etiology, diagnosis, treatment and future directions. Reprod. Biol. Endocrinol. 2018, 16, 121. [CrossRef] [PubMed]

5. Huang, Y.; Hu, C.; Ye, H.; Luo, R.; Fu, X.; Li, X.; Huang, J.; Chen, W.; Zheng, Y. Inflamm-Aging: A New Mechanism Affecting Premature Ovarian Insufficiency. J. Immunol. Res. 2019, 2019, 8069898. [CrossRef] [PubMed]

6. Ruan, X.; Kubba, A.; Aguilar, A.; Mueck, A.O. Use of cyproterone acetate/ethinylestradiol in polycystic ovary syndrome: Rationale and practical aspects. Eur. J. Contracept. Reprod. Health Care 2017, 22, $183-190$. [CrossRef] [PubMed]

7. Broughton, D.E.; Moley, K.H. Obesity and female infertility: Potential mediators of obesity's impact. Fertil. Steril. 2017, 107, 840-847.

8. Tomassetti, C.; D'Hooghe, T. Endometriosis and infertility: Insights into the causal link and management strategies. Best Pract. Res. Clin. Obstet. Gynaecol. 2018, 51, 25-33. [CrossRef] [PubMed]

9. Das, M.; Shehata, F.; Moria, A.; Holzer, H.; Son, W.Y.; Tulandi, T. Ovarian reserve, response to gonadotropins, and oocyte maturity in women with malignancy. Fertil. Steril. 2011, 96, 122-125. [CrossRef] [PubMed]

10. Lefebvre, T.; Mirallié, S.; Leperlier, F.; Reignier, A.; Barrière, P.; Fréour, T. Ovarian reserve and response to stimulation in women undergoing fertility preservation according to malignancy type. Reprod. BioMed. Online 2018, 37, 201-207. [CrossRef]

11. Salama, M.; Woodruff, T.K. Anticancer treatments and female fertility: Clinical concerns and role of oncologists in oncofertility practice. Expert Rev. Anticancer Ther. 2017, 17, 687-692. [CrossRef] [PubMed]

12. Levine, J.M.; Kelvin, J.F.; Quinn, G.P.; Gracia, C.R. Infertility in reproductive-age female cancer survivors. Cancer 2015, 121, 1532-1539. [CrossRef]

13. Algarroba, G.N.; Sanfilippo, J.S.; Valli-Pulaski, H. Female fertility preservation in the pediatric and adolescent cancer patient population. Best. Pract. Res. Clin. Obstet. Gynaecol. 2018, 48, 147-157. [CrossRef]

14. Bianchi, S.; Macchiarelli, G.; Micara, G.; Linari, A.; Boninsegna, C.; Aragona, C.; Rossi, G.; Cecconi, S.; Nottola, S.A. Ultrastructural markers of quality are impaired in human metaphase II aged oocytes: A comparison between reproductive and in vitro aging. J. Assist. Reprod. Genet. 2015, 32, 1343-1358. [CrossRef]

15. Lockwood, G.M. Social egg freezing: The prospect of reproductive 'immortality' or a dangerous delusion? Reprod. Biomed. Online 2011, 23, 334-340. [CrossRef]

16. Fritz, R.; Jindal, S. Reproductive aging and elective fertility preservation. J. Ovarian Res. 2018, 11, 66. [CrossRef] [PubMed]

17. Conforti, A.; Mascia, M.; Cioffi, G.; De Angelis, C.; Coppola, G.; De Rosa, P.; Pivonello, R.; Alviggi, C.; De Placido, G. Air pollution and female fertility: A systematic review of literature. Reprod. Biol. Endocrinol. 2018, 16, 117. [CrossRef] [PubMed]

18. Rashtian, J.; Chavkin, D.E.; Merhi, Z. Water and soil pollution as determinant of water and food quality/contamination and its impact on female fertility. Reprod. Biol. Endocrinol. 2019, 17, 5. [CrossRef]

19. Rossi, G.; Buccione, R.; Baldassarre, M.; Macchiarelli, G.; Palmerini, M.G.; Cecconi, S. Mancozeb exposure in vivo impairs mouse oocyte fertilizability. Reprod. Toxicol. 2006, 21, 216-219. [CrossRef] [PubMed]

20. Rossi, G.; Palmerini, M.G.; Macchiarelli, G.; Buccione, R.; Cecconi, S. Mancozeb adversely affects meiotic spindle organization and fertilization in mouse oocytes. Reprod. Toxicol. 2006, 22, 51-55. [CrossRef]

21. Cecconi, S.; Paro, R.; Rossi, G.; Macchiarelli, G. The effects of the endocrine disruptors dithiocarbamates on the mammalian ovary with particular regard to mancozeb. Curr. Pharm. Des. 2007, 13, 2989-3004. [CrossRef] [PubMed]

22. Palmerini, M.G.; Zhurabekova, G.; Balmagambetova, A.; Nottola, S.A.; Miglietta, S.; Belli, M.; Bianchi, S.; Cecconi, S.; Di Nisio, V.; Familiari, G.; et al. The pesticide Lindane induces dose-dependent damage to granulosa cells in an in vitro culture. Reprod. Biol. 2017, 17, 349-356. [CrossRef] [PubMed] 
23. Palmerini, M.G.; Belli, M.; Nottola, S.A.; Miglietta, S.; Bianchi, S.; Bernardi, S.; Antonouli, S.; Cecconi, S.; Familiari, G.; Macchiarelli, G. Mancozeb impairs the ultrastructure of mouse granulosa cells in a dose-dependent manner. J. Reprod. Dev. 2018, 64, 75-82. [CrossRef] [PubMed]

24. Alvarez, S. Do some addictions interfere with fertility? Fertil. Steril. 2015, 103, 22-26. [CrossRef]

25. Medrano, J.V.; Andrés, M.D.M.; García, S.; Herraiz, S.; Vilanova-Pérez, T.; Goossens, E.; Pellicer, A. Basic and Clinical Approaches for Fertility Preservation and Restoration in Cancer Patients. Trends Biotechnol. 2018, 36, 199-215. [CrossRef] [PubMed]

26. Martinez-Madrid, B.; Camboni, A.; Dolmans, M.M.; Nottola, S.; Van Langendonckt, A.; Donnez, J. Apoptosis and ultrastructural assessment after cryopreservation of whole human ovaries with their vascular pedicle. Fertil. Steril. 2007, 87, 1153-1165. [CrossRef]

27. Camboni, A.; Martinez-Madrid, B.; Dolmans, M.M.; Amorim, C.A.; Nottola, S.A.; Donnez, J.; Van Langendonckt, A. Preservation of fertility in young cancer patients: Contribution of transmission electron microscopy. Reprod. BioMed. Online 2008, 17, 136-150. [CrossRef]

28. Camboni, A.; Martinez-Madrid, B.; Dolmans, M.M.; Nottola, S.; Van Langendonckt, A.; Donnez, J. Autotransplantation of frozen-thawed ovarian tissue in a young woman: Ultrastructure and viability of grafted tissue. Fertil. Steril. 2008, 90, 1215-1218. [CrossRef] [PubMed]

29. Nottola, S.A.; Camboni, A.; Van Langendonckt, A.; Demylle, D.; Macchiarelli, G.; Dolmans, M.M.; Martinez-Madrid, B.; Correr, S.; Donnez, J. Cryopreservation and xenotransplantation of human ovarian tissue: An ultrastructural study. Fertil. Steril. 2008, 90, 23-32. [CrossRef] [PubMed]

30. Nottola, S.A.; Cecconi, S.; Bianchi, S.; Motta, C.; Rossi, G.; Continenza, M.A.; Macchiarelli, G. Ultrastructure of isolated mouse ovarian follicles cultured in vitro. Reprod. Biol. Endocrinol. 2011, 9, 3. [CrossRef]

31. Khalili, M.A.; Shahedi, A.; Ashourzadeh, S.; Nottola, S.A.; Macchiarelli, G.; Palmerini, M.G. Vitrification of human immature oocytes before and after in vitro maturation: A review. J. Assist. Reprod. Genet. 2017, 34, 1413-1426. [CrossRef]

32. Fisch, B.; Abir, R. Female fertility preservation: Past, present and future. Reproduction 2018, 156, F11-F27. [CrossRef]

33. Luconi, M.; Torcia, S.; Grillo, D.; Fiorenza, M.T.; Forti, G.; Mangia, F.; Baldi, E. Enhancement of mouse sperm motility by the PI3-kinase inhibitor LY294002 does not result in toxic effects on preimplantation embryo development. Hum. Reprod. 2005, 20, 3500-3504. [CrossRef]

34. Tardif, S.; Madamidola, O.A.; Brown, S.G.; Frame, L.; Lefièvre, L.; Wyatt, P.G.; Barratt, C.L.; Martins Da Silva, S.J. Clinically relevant enhancement of human sperm motility using compounds with reported phosphodiesterase inhibitor activity. Hum. Reprod. 2014, 29, 2123-2135. [CrossRef]

35. De Rooij, D.G. The nature and dynamics of spermatogonial stem cells. Development 2017, 144, 3022-3030. [CrossRef]

36. Ginsburg, M.; Snow, M.H.A.M. Primordial germ cells in the mouse embryo during gastrulation. Development 1990, 110, 521-528.

37. Gondos, B. Comparative studies of normal and neoplastic ovarian germ cells: 1 . Ultrastructure of oogonia and intercellular bridges in the fetal ovary. Int. J. Gynecol. Pathol. 1987, 6, 114-123. [CrossRef]

38. Hunt, P.A.; Hassold, T.J. Human female meiosis: What makes a good egg go bad? Trends Genet. 2008, 24, 86-93. [CrossRef]

39. Johnson, J.; Canning, J.; Kaneko, T.; Pru, J.K.; Tilly, J.L. Germline stem cells and follicular renewal in the postnatal mammalian ovary. Nature 2004, 428, 145. [CrossRef]

40. Bhartiya, D.; Parte, S.; Patel, H.; Sriraman, K.; Zaveri, K.; Hinduja, I. Novel action of FSH on stem cells in adult mammalian ovary induces postnatal oogenesis and primordial follicle assembly. Stem Cells Int. 2016, 2016, 5096596. [CrossRef]

41. Porras-Gómez, T.J.; Moreno-Mendoza, N. Neo-oogenesis in mammals. Zygote 2017, 25, 404-422. [CrossRef]

42. Wandji, S.A.; Srsen, V.; Voss, A.K.; Eppig, J.J.; Fortune, J.E. Initiation in vitro of growth of bovine primordial follicles. Biol. Reprod. 1996, 55, 942-948. [CrossRef]

43. Macchiarelli, G.; Vizza, E.; Nottola, S.A.; Familiari, G.; Motta, P.M. Cellular and microvascular changes of the ovarian follicle during folliculogenesis: A scanning electron microscopic study. Arch. Histol. Cytol. 1992, 55, 191-204. [CrossRef]

44. Eppig, J.J.; O’Brien, M.J. Development in vitro of mouse oocytes from primordial follicles. Biol. Reprod. 1996, 54, 197-207. [CrossRef] 
45. Sánchez, F.; Smitz, J. Molecular control of oogenesis. Biochim. Biophys. Acta 2012, 1822, 1896-1912. [CrossRef]

46. Fair, T. Mammalian oocyte development: Checkpoints for competence. Reprod. Fertil. Dev. 2009, $22,13-20$. [CrossRef]

47. Richards, J.S.; Jahnsen, T.; Hedin, L.; Lifka, J.; Ratoosh, S.; Durica, J.M.; Goldring, N.B. Ovarian follicular development: From physiology to molecular biology. Recent Prog. Horm. Res. 1987, 43, 231-276.

48. Bao, B.; Garverick, H.A. Expression of steroidogenic enzyme and gonadotropin receptor genes in bovine follicles during ovarian follicular waves: A review. J. Anim. Sci. 1998, 76, 1903-1921. [CrossRef]

49. Fortune, J.; Eppig, J. Effects of gonadotropins on steroid secretion by infantile and juvenile mouse ovaries in vitro. Endocrinology 1979, 105, 760-768. [CrossRef]

50. Oktay, K.; Briggs, D.; Gosden, R.G. Ontogeny of follicle-stimulating hormone receptor gene expression in isolated human ovarian follicles. J. Clin. Endocrinol. Metab. 1997, 82, 3748-3751. [CrossRef]

51. Roy, S.K.; Albee, L. Requirement for follicle-stimulating hormone action in the formation of primordial follicles during perinatal ovarian development in the hamster. Endocrinology 2000, 141, 4449-4456. [CrossRef] [PubMed]

52. Allan, C.M.; Wang, Y.; Jimenez, M.; Marshan, B.; Spaliviero, J.; Illingworth, P.; Handelsman, D.J. Follicle-stimulating hormone increases primordial follicle reserve in mature female hypogonadal mice. J. Endocrinol. 2006, 188, 549-557. [CrossRef]

53. Edson, M.A.; Nagaraja, A.K.; Matzuk, M.M. The mammalian ovary from genesis to revelation. Endocr. Rev. 2009, 30, 624-712. [CrossRef]

54. Cecconi, S.; Ciccarelli, C.; Barberi, M.; Macchiarelli, G.; Canipari, R. Granulosa cell-oocyte interactions. Eur. J. Obstet. Gynecol. Reprod. Biol. 2004, 115, S19-S22. [CrossRef] [PubMed]

55. Zuccotti, M.; Merico, V.; Cecconi, S.; Redi, C.A.; Garagna, S. What does it take to make a evelopmentally competent mammalian egg? Hum. Reprod. Update 2011, 17, 525-540. [CrossRef] [PubMed]

56. Hsueh, A.; Dahl, K.D.; Vaughan, J.; Tucker, E.; Rivier, J.; Bardin, C.W.; Vale, W. Heterodimers and homodimers of inhibin subunits have different paracrine action in the modulation of luteinizing hormone-stimulated androgen biosynthesis. Proc. Natl. Acad. Sci. USA 1987, 84, 5082-5086. [CrossRef]

57. Alak, B.M.; Smith, G.D.; Woodruff, T.K.; Stouffer, R.L.; Wolf, D.P. Enhancement of primate oocyte maturation and fertilization in vitro by inhibin A and activin A. Fertil. Steril. 1996, 66, 646-653. [CrossRef]

58. Bleil, J.D.; Wassarman, P.M. Galactose at the nonreducing terminus of O-linked ligosaccharides of mouse egg zona pellucida glycoprotein ZP3 is essential for the glycoprotein's sperm receptor activity. Proc. Natl. Acad. Sci. USA 1988, 85, 6778-6782. [CrossRef]

59. Sinowatz, F.; Kölle, S.; Töpfer-Petersen, E. Biosynthesis and expression of zona pellucida glycoproteins in mammals. Cells Tissues Organs 2001, 168, 24-35. [CrossRef] [PubMed]

60. Van Santbrink, E.J.; Hop, W.C.; van Dessel, T.J.; de Jong, F.H.; Fauser, B.C. Decremental follicle-stimulating hormone and dominant follicle development during the normal menstrual cycle. Fertil. Steril. 1995, 64, 37-43. [CrossRef]

61. Tesfaye, D.; Gebremedhn, S.; Salilew-Wondim, D.; Hailay, T.; Hoelker, M.; Grosse-Brinkhaus, C.; Schellander, K. MicroRNAs: Tiny molecules with a significant role in mammalian follicular and oocyte development. Reproduction 2018, 155, R121-R135. [CrossRef]

62. Liu, W.; Xin, Q.; Wang, X.; Wang, S.; Wang, H.; Zhang, W.; Yang, Y.; Zhang, Y.; Zhang, Z.; Wang, C.; et al. Estrogen receptors in granulosa cells govern meiotic resumption of pre-ovulatory oocytes in mammals. Cell Death Dis. 2017, 8, e2662. [CrossRef]

63. Richards, J.S.; Ascoli, M. Endocrine, Paracrine, and Autocrine Signaling Pathways That Regulate Ovulation. Trends Endocrinol. Metab. 2018, 29, 313-325. [CrossRef]

64. Li, R.; Albertini, D.F. The road to maturation: Somatic cell interaction and self-organization of the mammalian oocyte. Nat. Rev. Mol. Cell Biol. 2013, 14, 141-152. [CrossRef]

65. Dolmans, M.M.; Luyckx, V.; Donnez, J.; Andersen, C.Y.; Greve, T. Risk of transferring malignant cells with transplanted frozen-thawed ovarian tissue. Fertil. Steril. 2013, 99, 1514-1522. [CrossRef]

66. Eppig, J.J.; Schroeder, A.C. Capacity of mouse oocytes from preantral follicles to undergo embryogenesis and development to live young after growth, maturation, and fertilization in vitro. Biol. Reprod. 1989, 41, 268-276. [CrossRef]

67. Guzel, Y.; Oktem, O. Understanding follicle growth in vitro: Are we getting closer to obtaining mature oocytes from in vitro-grown follicles in human? Mol. Reprod. Dev. 2017, 84, 544-559. [CrossRef] 
68. O’Brien, M.J.; Pendola, J.K.; Eppig, J.J. A revised protocol for in vitro development of mouse oocytes from primordial follicles dramatically improves their developmental competence. Biol. Reprod. 2003, 68, 1682-1686. [CrossRef]

69. Hasegawa, A.; Mochida, N.; Ogasawara, T.; Koyama, K. Pup birth from mouse oocytes in preantral follicles derived from vitrified and warmed ovaries followed by in vitro growth, in vitro maturation, and in vitro fertilization. Fertil. Steril. 2006, 86, 1182-1192. [CrossRef]

70. Mochida, N.; Akatani-Hasegawa, A.; Saka, K.; Ogino, M.; Hosoda, Y.; Wada, R.; Sawai, H.; Shibahara, H. Live births from isolated primary/early secondary follicles following a multistep culture without organ culture in mice. Reproduction 2013, 146, 37-47. [CrossRef] [PubMed]

71. Lee, J.; Kim, E.J.; Kong, H.S.; Youm, H.W.; Kim, S.K.; Lee, J.R.; Suh, C.S.; Kim, S.H. Comparison of the oocyte quality derived from two-dimensional follicle culture methods and developmental competence of in vitro grown and matured oocytes. BioMed Res. Int. 2018, 7907092. [CrossRef] [PubMed]

72. Cecconi, S. Growth and differentiation of small ovarian follicles in mammals: Problems and future perspectives. J. Reprod. Dev. 2002, 48, 431-435. [CrossRef]

73. Cecconi, S.; D'Aurizio, R.; Colonna, R. Role of antral follicle development and cumulus cells on in vitro fertilization of mouse oocytes. J. Reprod. Fertil. 1996, 107, 207-214. [CrossRef] [PubMed]

74. Cecconi, S.; Barboni, B.; Coccia, M.; Mattioli, M. In vitro development of sheep preantral follicles. Biol. Reprod. 1999, 60, 594-601. [CrossRef] [PubMed]

75. Cecconi, S.; Capacchietti, G.; Russo, V.; Berardinelli, P.; Mattioli, M.; Barboni, B. In vitro growth of preantral follicles isolated from cryopreserved ovine ovarian tissue. Biol. Reprod. 2004, 70, 12-17. [CrossRef] [PubMed]

76. Srividya, D.; Praveen Chakravarthi, V.; Kona, S.; Siva Kumar, A.; Brahmaiah, K.V.; Rao, V.H. Expression of kit ligand and insulin-like growth factor binding protein 3 during in vivo or in vitro development of ovarian follicles in sheep. Reprod. Domest. Anim. 2017, 52, 661-671. [CrossRef] [PubMed]

77. Barboni, B.; Russo, V.; Cecconi, S.; Curini, V.; Colosimo, A.; Garofalo, M.L.; Capacchietti, G.; Di Giacinto, O.; Mattioli, M. In vitro grown sheep preantral follicles yield oocytes with normal nuclear-epigenetic maturation. PLoS ONE 2011, 6, e27550. [CrossRef]

78. Lee, K.Y.; Mooney, D.J. Alginate: Properties and biomedical applications. Prog. Polym. Sci. 2012, 37, $106-126$. [CrossRef]

79. Xu, M.; Kreeger, P.K.; Shea, L.D.; Woodruff, T.K. Tissue-engineered follicles produce live, fertile offspring. Tissue Eng. 2006, 12, 2739-2746. [CrossRef]

80. Shea, L.D.; Woodruff, T.K.; Shikanov, A. Bioengineering the Ovarian Follicle Microenvironment. Annu. Rev. Biomed. Eng. 2014, 16, 29-52. [CrossRef]

81. Higuchi, C.M.; Maeda, Y.; Horiuchi, T.; Yamazaki, Y. A Simplified method for three-dimensional (3-D) ovarian tissue culture yielding oocytes competent to produce full-term offspring in mice. PLoS ONE 2015, 10, e0143114. [CrossRef]

82. Gosden, R.G.; Picton, H.M.; Nugent, D.; Rutherford, A.J. Gonadal tissue cryopreservation: Clinical objectives and practical prospects. Hum. Fertil. 1999, 2, 107-114. [CrossRef]

83. Hovatta, O.; Wright, C.; Krausz, T.; Hardy, K.; Winston, R.M. Human primordial, primary and secondary ovarian follicles in long-term culture: Effect of partial isolation. Hum. Reprod. 1999, 14, 2519-2524. [CrossRef] [PubMed]

84. Telfer, E.E.; McLaughlin, M.; Ding, C.; Thong, K.J. A two-step serum-free culture system supports development of human oocytes from primordial follicles in the presence of activin. Hum. Reprod. 2008, 23, 1151-1158. [CrossRef] [PubMed]

85. Li, J.; Kawamura, K.; Cheng, Y.; Liu, S.; Klein, C.; Liu, S.; Duan, E.K.; Hsueh, A.J. Activation of dormant ovarian follicles to generate mature eggs. Proc. Natl. Acad. Sci. USA 2010, 107, 10280-10284. [CrossRef]

86. Kawamura, K.; Cheng, Y.; Suzuki, N.; Deguchi, M.; Sato, Y.; Takae, S.; Ho, C.H.; Kawamura, N.; Tamura, M.; Hashimoto, S.; et al. Hippo signaling disruption and Akt stimulation of ovarian follicles for infertility treatment. Proc. Natl. Acad. Sci. USA 2013, 110, 17474-17479. [CrossRef]

87. Maidarti, M.; Clarkson, Y.L.; McLaughlin, M.; Anderson, R.A.; Telfer, E.E. Inhibition of PTEN activates bovine non-growing follicles in vitro but increases DNA damage and reduces DNA repair response. Hum. Reprod. 2019, 34, 297-307. [CrossRef] 
88. Laronda, M.M.; Duncan, F.E.; Hornick, J.E.; Xu, M.; Pahnke, J.E.; Whelan, K.A.; Shea, L.D.; Woodruff, T.K. Alginate encapsulation supports the growth and differentiation of human primordial follicles within ovarian cortical tissue. J. Assist. Reprod. Genet. 2014, 31, 1013-1028. [CrossRef]

89. Xiao, S.; Zhang, J.; Romero, M.M.; Smith, K.N.; Shea, L.D.; Woodruff, T.K. In vitro follicle growth supports human oocyte meiotic maturation. Sci. Rep. 2015, 5, 17323. [CrossRef] [PubMed]

90. McLaughlin, M.; Albertini, D.F.; Wallace, W.H.B.; Anderson, R.A.; Telfer, E.E. Metaphase II oocytes from human unilaminar follicles grown in a multi-step culture system. Mol. Hum. Reprod. 2018, 24, $135-142$. [CrossRef] [PubMed]

91. Martelli, A.; Palmerini, M.G.; Russo, V.; Rinaldi, C.; Bernabò, N.; Di Giacinto, O.; Berardinelli, P.; Nottola, S.A.; Macchiarelli, G.; Barboni, B. Blood vessel remodeling in pig ovarian follicles during the periovulatory period: An immunohistochemistry and SEM-corrosion casting study. Reprod. Biol. Endocrinol. 2009, 7, 72. [CrossRef]

92. Palmerini, M.G.; Nottola, S.A.; Tunjung, W.A.; Kadowaki, A.; Bianchi, S.; Cecconi, S.; Sato, E.; Macchiarelli, G. EGF-FSH supplementation reduces apoptosis of pig granulosa cells in co-culture with cumulus-oocyte complexes. Biochem. Biophys. Res. Commun. 2016, 481, 159-164. [CrossRef]

93. Jimenez, C.R.; De Azevedo, J.L.; Silveira, R.G.; Penitente-Filho, J.; Carrascal-Triana, E.L.; Zolini, A.M.; Araujo, V.R.; Torres, C.; Gonçalves, W.G. Effects of IGF-1 on In Vitro Culture of Bovine Preantral Follicles are Dose-Dependent. Reprod. Domest. Anim. 2016, 51, 435-444. [CrossRef]

94. Silva, A.W.B.; Ribeiro, R.P.; Menezes, V.G.; Barberino, R.S.; Passos, J.R.S.; Dau, A.M.P.; Costa, J.J.N.; Melo, L.R.F.; Bezerra, F.T.G.; Donato, M.A.M.; et al. Expression of TNF- $\alpha$ system members in bovine ovarian follicles and the effects of TNF- $\alpha$ or dexamethasone on preantral follicle survival, development and ultrastructure in vitro. Anim. Reprod. Sci. 2017, 182, 56-68. [CrossRef]

95. Palmerini, M.G.; Nottola, S.A.; Leoni, G.G.; Succu, S.; Borshi, X.; Berlinguer, F.; Naitana, S.; Bekmukhambetov, Y.; Macchiarelli, G. In vitro maturation is slowed in prepubertal lamb oocytes: Ultrastructural evidences. Reprod. Biol. Endocrinol. 2014, 12, 115. [CrossRef]

96. Leoni, G.G.; Palmerini, M.G.; Satta, V.; Succu, S.; Pasciu, V.; Zinellu, A.; Carru, C.; Macchiarelli, G.; Nottola, S.A.; Naitana, S.; Berlinguer, F. Differences in the kinetic of the first meiotic division and in active mitochondrial distribution between prepubertal and adult oocytes mirror differences in their developmental competence in a sheep model. PLoS ONE 2015, 10, e0124911. [CrossRef]

97. Factsheet: The European Day for Organ Donation and Transplantation. Available online: https://www.edqm. eu/sites/default/files/factsheet_organ_tissue_cell_donation_eodd_2018.pdf (accessed on 12 January 2019).

98. Murphy, S.V.; Atala, A. 3D bioprinting of tissues and organs. Nat. Biotechnol. 2014, 32, 773-785. [CrossRef]

99. Vijayavenkataraman, S.; Yan, W.C.; Lu, W.F.; Wang, C.H.; Fuh, J.Y.H. 3D bioprinting of tissues and organs for regenerative medicine. Adv. Drug Deliv. Rev. 2018, 132, 296-332. [CrossRef]

100. Huh, D.; Matthews, B.D.; Mammoto, A.; Montoya-Zavala, M.; Hsin, H.Y.; Ingber, D.E. Reconstituting organ-level lung functions on a chip. Science 2010, 328, 1662-1668. [CrossRef]

101. Sonntag, F.; Schilling, N.; Mader, K.; Gruchow, M.; Klotzbach, U.; Lindner, G.; Horland, R.; Wagner, I.; Lauster, R.; Howitz, S.; et al. Design and prototyping of a chip-based multi-micro-organoid culture system for substance testing, predictive to human (substance) exposure. J. Biotechnol. 2010, 148, 70-75. [CrossRef]

102. Paulini, F.; Vilela, J.M.; Chiti, M.C.; Donnez, J.; Jadoul, P.; Dolmans, M.M.; Amorim, C.A. Survival and growth of human preantral follicles after cryopreservation of ovarian tissue, follicle isolation and short-term xenografting. Reprod. BioMed. Online 2016, 33, 425-432. [CrossRef]

103. Laronda, M.M.; Rutz, A.L.; Xiao, S.; Whelan, K.A.; Duncan, F.E.; Roth, E.W.; Woodruff, T.K.; Shah, R.N. A bioprosthetic ovary created using $3 \mathrm{D}$ printed microporous scaffolds restores ovarian function in sterilized mice. Nat. Commun. 2017, 8, 15261. [CrossRef]

104. Hassanpour, A.; Talaei-Khozani, T.; Kargar-Abarghouei, E.; Razban, V.; Vojdani, Z. Decellularized human ovarian scaffold based on a sodium lauryl ester sulfate (SLES)-treated protocol, as a natural three-dimensional scaffold for construction of bioengineered ovaries. Stem Cell Res. Ther. 2018, 9, 252. [CrossRef] [PubMed]

105. Liverani, L.; Raffel, N.; Fattahi, A.; Preis, A.; Hoffmann, I.; Boccaccini, A.R.; Beckmann, M.W.; Dittrich, R. Electrospun patterned porous scaffolds for the support of ovarian follicles growth: A feasibility study. Sci. Rep. 2019, 9, 1150. [CrossRef] [PubMed]

106. Antonino, D.C.; Soares, M.M.; Júnior, J.M.; de Alvarenga, P.B.; Mohallem, R.F.F.; Rocha, C.D.; Vieira, L.A.; de Souza, A.G.; Beletti, M.E.; Alves, B.G.; et al. Three-dimensional levitation culture improves in-vitro growth of secondary follicles in bovine model. Reprod. BioMed. Online 2019, 38, 300-311. [CrossRef] [PubMed] 
107. Skory, R.M.; Xu, Y.; Shea, L.D.; Woodruff, T.K. Engineering the ovarian cycle using in vitro follicle culture. Hum. Reprod. 2015, 30, 1386-1395. [CrossRef] [PubMed]

108. Silva, J.R.; van den Hurk, R.; Figueiredo, J.R. Ovarian follicle development in vitro and oocyte competence: Advances and challenges for farm animals. Domest. Anim. Endocrinol. 2016, 55, 123-135. [CrossRef]

109. Baba, T.; Ting, A.Y.; Tkachenko, O.; Xu, J.; Stouffer, R.L. Direct actions of androgen, estrogen and anti-Müllerian hormone on primate secondary follicle development in the absence of FSH in vitro. Hum. Reprod. 2017, 32, 2456-2464. [CrossRef]

110. Jones, A.S.K.; Shikanov, A. Follicle development as an orchestrated signaling network in a 3D organoid. J. Biol. Eng. 2019, 13, 2. [CrossRef]

111. Baysal, Ö.; Hamilton, J.A.M.; Hamilton, C.J.C.M.; Braat, D.D.M.; Beerendonk, C.C.M.; Nelen, W.L.D.M. Clinical practice guidelines for fertility preservation in young women undergoing gonadotoxic treatment: An overview and critical appraisal of methodological quality and content. Reprod. BioMed. Online 2018, 37, 60-70. [CrossRef]

112. Woodruff, T.K. From the bench to bedside to babies: Translational medicine made possible by funding multidisciplinary team science. J. Assist. Reprod. Genet. 2013, 30, 1249-1253. [CrossRef] [PubMed]

113. Network FertiPROTEKT. Available online: www.fertiprotekt.com (accessed on 20 February 2019).

114. Oncofertility Consortium Network. Available online: www.oncofertility.northwestern.edu (accessed on 20 February 2019).

115. Ethics Committee of the American Society for Reproductive Medicine. Fertility preservation and reproduction in patients facing gonadotoxic therapies: An Ethics Committee opinion. Fertil. Steril. 2018, 110, 380-386. [CrossRef] [PubMed]

116. Hikabe, O.; Hamazaki, N.; Nagamatsu, G.; Obata, Y.; Hirao, Y.; Hamada, N.; Shimamoto, S.; Imamura, T.; Nakashima, K.; Saitou, M.; Hayashi, K. Reconstitution in vitro of the entire cycle of the mouse female germ line. Nature 2016, 539, 299-303. [CrossRef] [PubMed]

(C) 2019 by the authors. Licensee MDPI, Basel, Switzerland. This article is an open access article distributed under the terms and conditions of the Creative Commons Attribution (CC BY) license (http://creativecommons.org/licenses/by/4.0/). 